\title{
EFFICACY OF POSTEMERGENCE HERBICIDES FOR CONTROLLING CURLED DOCK (RUMEX CRISPUS L.) IN WHEAT CROPS
}

\author{
IQBAL, M. F. $.^{1,3}-$ SHAD, G. M. ${ }^{2}-$ FENG, Y. L. ${ }^{1 *}-$ LIU, M. C. $^{1}-$ WANG, S. $^{1}-$ LU, X. R. ${ }^{1}-$ \\ IQBAL, Z. ${ }^{4}-$ TARIQ, M. ${ }^{5}$ \\ ${ }^{1}$ College of Bioscience and Biotechnology, Shenyang Agricultural University No. 120 Dongling \\ Road, Shenyang, Liaoning Province 110866, China \\ ${ }^{2}$ Department of Pest Warning and Quality Control of Pesticides, Gujrat, Pakistan \\ ${ }^{3}$ Department of Agriculture, Adaptive Research Station Sialkot, Punjab-Pakistan \\ ${ }^{4}$ University of Veterinary and Animal Sciences, Sub-campus, Narowal, Punjab, Pakistan \\ ${ }^{5}$ Department of Entomology, PMAS-Arid Agriculture University, Rawalpindi, Pakistan \\ *Corresponding author \\ e-mail:yl_feng@tom.com; phone: +86-24-8848-7163; fax: +86-24-8849-2799
}

(Received 29 $9^{\text {th }}$ Apr 2019; accepted $11^{\text {th }}$ Jul 2019)

\begin{abstract}
Curled dock (Rumex crispus L.) is a common perennial toxic weed species in wheat crop. To our knowledge, this is the distinctive scientific study proposed to evaluate the efficacy of four new chemical combinations of herbicides viz. Starane-M @ $750 \mathrm{ml} \mathrm{ha}^{-1}$; Clean Wave @ $800 \mathrm{ml} \mathrm{ha}^{-1}$; Broad-X @ $875 \mathrm{ml} \mathrm{ha}^{-1}$ and Allymax @ $35 \mathrm{~g} \mathrm{ha}^{-1}$ sprayed as foliar application in wheat crop. These applications conducted with control treatment for proper comparison. Results illustrated that broad-X afforded highly significant $(\mathrm{P}<0.001)$ potential for controlling this weed resulting in strong positive $R^{2}(0.84)$ with RMSE (0.69 \& 0.80) compared to clean wave proved the evidence for model fitness. Significant $(\mathrm{P}<0.01)$ mortality of curled dock catalyzed by mist spraying of broad-X $(91.16 \% ; 91.55 \%)$ conferred better control efficacy 30 days after treatment. Significant $(P<0.001)$ increase in yield $(33.29 \%)$ was observed as a consequent of spraying broad-X followed by clean wave $(29.63 \%)$ herbicides. The interaction of leaf area $\left(\mathrm{cm}^{2}\right)$ with herbicides correlated as predicted, which indicated that manual quantification method is suitable. The productivity increased significantly by spraying broad-X (33.29\%) and clean wave (29.63\%) compared to control. According to our findings, the new chemical herbicides obtained a high potential for controlling this invasive weed in wheat crops.
\end{abstract}

Keywords: broadleaves weed, mortality, quantification, weed yield interaction, Gujrat, Punjab, Pakistan

\section{Introduction}

Being a significant bellicose weed, curled dock (Rumex crispus L.) belongs to Polygonaceae family, native to South-East Asia (Schuster et al., 2015) and now has become a severe problem in irrigated wheat ecosystems in Gujrat, Punjab-Pakistan. Rumex obtusifolius is another species of this family present in arable soils (Marshall et al., 2003); however, broadleaf dock ( $R$. dentatus) density was present in different locations of Dera Ismail Khan (Marwat et al., 2013). Weed competition has become a significant discretion in limiting the yield of any crop (Siddiqui and Bajwa, 2010). Weeds fight with the crop for the place, fluorescence, moisture, nutrient and reduce the yield (Shehzad et al., 2013). Weeds can infest any ecosystems; therefore, researchers focus on how to weed diversity affect crop yield (Davis et al., 2009). 
Herbicide resistance created many problems (Délye et al., 2013a) in response to its numerous applications across many years (Moss et al., 2019). Herbicide resistance alleles create pleiotropic effects on a weed's life cycle (Délye et al., 2013b). The rising figure of resistant weed biotypes is a critical fear for agriculture as no new herbicide mode of action has been marketed for over 30 years (Duke, 2012; Westwood et al., 2018).

Further, as pointed out that the effectiveness of herbicides depends upon the proper time of application, dose and selectivity of herbicides (Steckel et al., 1997), high weeds intensity and competition cause maximum reduction in yield (Chaudhry et al., 2008; Dalley et al., 2006). Weeds account for a significant 37-50\% reduction in yield (Nayyar et al., 1994; Waheed et al., 2009) among them curled dock is a significant pest of many agriculture crops that not only reduce and also spoil the quality of the produce. Its control measures are ineffective in most of the plants due to the taproot system (Zaller, $2004 a$, b). High weeds intensity and competition with crops affected negatively reducing the yield of wheat crops (Dalley et al., 2006).

The weed infestations suppress the quality and quantity of crops; directly effects on economic and increasing the chance of spreading diseases (Marwat et al., 2008). Ecological surveys carried out in different areas of Pakistan revealed that curled dock seeds are prolific (Qureshi et al., 2009). Curled dock germinated from seed but also regenerate from the underground part of roots (Zaller, 2004b; Zimdahl, 2018).

The negligence factor considered a vital role responsible for weed infestation; hence, there is a dire need to develop effective management policies. However, researchers would focus on intensity, competition between weed ecosystem and appropriate application of proper new chemical herbicides are essential factors in determining the yield losses. The researchers would adopt better weed management strategies (WMS) for controlling this invasive weed in the ecosystem of Pakistan (Fig. 1).

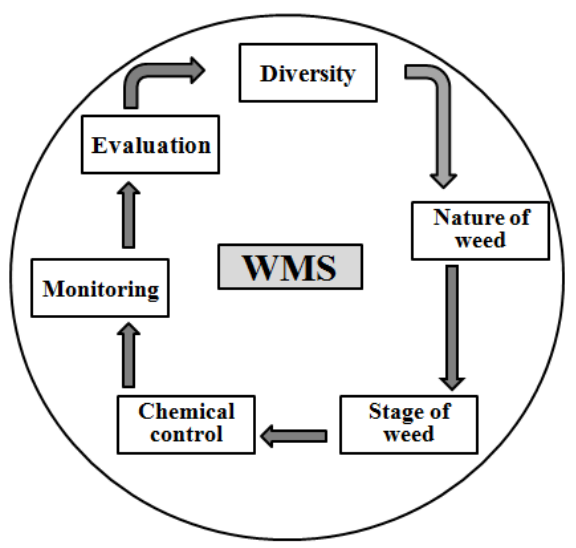

Figure 1. Weed management strategies (WMS) for controlling curled dock

The experiment suggested that the habitat of curled dock is annual present at roadsides, near the bank of ponds and non-cropped areas. In the arable areas, invasive weeds easily controlled by herbicides compared to agricultural lands (Crone et al., 2009). Nevertheless, in the present scenario curled dock (Rumex crispus L.) species shifted from non-cropped fellow lands to wheat crops, which creates alarming situations for researchers. This distinctive study aimed to screen out the best one herbicide for effective weed control, ensure better management and ultimately increasing the yield of 
the wheat crops. The hypothesis integrated that curled dock could control by foliar application of a mixture of two herbicides except one. Due to its hard phenotypic nature, new chemical combinations of herbicides tested for examining its better management. To sum up, the overall study planned to evaluate the response of new combinations of chemicals available in the market of Punjab, Pakistan. These chemicals sprayed to control curled dock according to its maximum abundance in wheat crops selected after extensive survey at different locations at Gujrat, Punjab-Pakistan during two consecutive years.

\section{Materials and methods}

\section{Study sites}

Table 1 shows two years of study designed after extensive field survey in Gujranwala division in order to evaluate the efficacy of four newly introduced combinations of herbicides for controlling Curled dock in wheat crop compared to control.

Table 1. List of herbicides used in the study

\begin{tabular}{c|c|c|c|c}
\hline Chemical name & $\begin{array}{c}\text { Trade } \\
\text { name }\end{array}$ & $\begin{array}{c}\text { Rate } \\
\left(\mathbf{g ~ a i ~ h a}^{-\mathbf{1}}\right)\end{array}$ & Chemical family & $\begin{array}{c}\text { Dose } \\
\left(\mathbf{m l ~ h a}^{-\mathbf{1}}\right)\end{array}$ \\
\hline Control & Control & - & - & - \\
\hline Fluroxypyr + MCPA & Starane-M & $239+956$ & $\begin{array}{c}\text { Phenoxy acetic } \\
\text { acid }\end{array}$ & 750 \\
\hline Fluroxypyr + Aminopyralid + MCPA & Clean Wave & $350+25+956$ & $\begin{array}{c}\text { Phenoxy acetic } \\
\text { acid }\end{array}$ & 800 \\
\hline Fluroxypyr + Clopyralid + MCPA & Broad-X & $\begin{array}{c}199.75+300+799 . \\
25\end{array}$ & $\begin{array}{c}\text { Pyridine } \\
\text { carboxylic acid }\end{array}$ & 875 \\
\hline Metsulfuron + Tribenuron & Allymax & $357.5+357.5$ & Sulfonylurea & $35 \mathrm{~g}$ \\
\hline
\end{tabular}

$\mathrm{g}=$ gram, ai $=$ active ingredient, $\mathrm{ha}^{-1}=$ per hectare, $\mathrm{ml}=$ millilitre

The authors selected different sites in two villages of Tehsil Gujrat and Kharian in our experiments where the maximum abundance of this toxic weed recorded in wheat crops during 2015-16 and 2016-17 (Fig. 2).

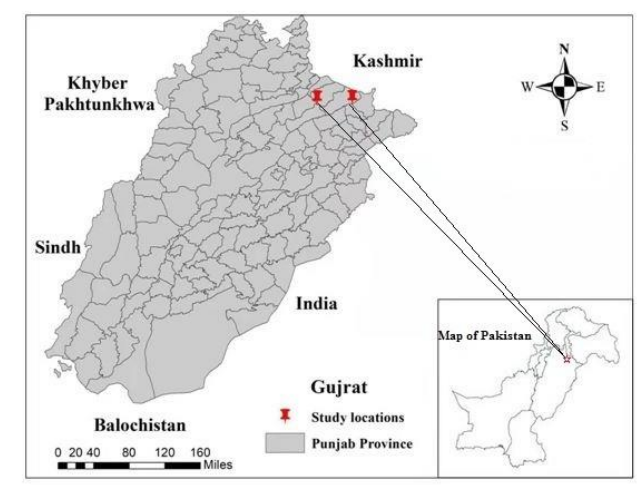

Figure 2. ArcGIS map showing experimental sites in District Gujrat, Punjab-Pakistan 


\section{Experimental outline}

The trial was exhibited by randomized complete block design (RCBD) with three replications having the net plot size for all treatments were $65 \times 60 \mathrm{~m}$, but for each treatment, the area designed was $13 \times 20 \mathrm{~m}$. Each plot or block was separated clearly by making paths (Dalga et al., 2014), and the experiment repeated in time, keeping in view the abundance of the curled dock. The wheat variety Faisalabad-2008 was cultivated in well-prepared soil using seed @ $125 \mathrm{~kg} \mathrm{ha}^{-1}$ collected from Punjab Seed Corporation, Gujranwala. Di-ammonium Phosphate (DAP) $125 \mathrm{~kg} \mathrm{ha}^{-1}$ and $\mathrm{K}_{2} \mathrm{O}$ (SOP) @ $62 \mathrm{~kg} \mathrm{ha}^{-1}$ were applied as a basal dose after planking by drilling method on last week of November each year. The wheat crops irrigated 30 days after cultivation and urea broadcasted uniformly in the field @ $125 \mathrm{~kg} \mathrm{ha}^{-1}$.

\section{Foliar application}

Herbicides sprayed at proper moist conditions with manually operated Knapsack hand sprayer with required spray and volume of water kept up to $300 \mathrm{~L} \mathrm{ha}^{-1}$ using T-Jet nozzle with a droplet size of $225 \mu \mathrm{m}$ and a fine mist of 2 PSI 45 days after sowing.

\section{Data collection}

The data collected randomly by quadratic ring using the diagonal method at three different locations in each treatment. The total populations of curled dock recorded before foliar application from each block/treatment. The wheat crop visited fifteen (15) days after applications, counted weed populations, and the same procedure adopted at the interval of 30 days each year, however, the experimental field monitored throughout the growing season. The mortality (\%) of weed calculated (Alvi et al., 2004).

\section{Leaf area measurement}

Leaves from each treatment collected randomly for leaf area determination. These leaves placed on a white rectangular sketch of the whiteboard, calculated the leaf length $(\mathrm{cm})$ and a maximum width of the leaf and multiplied by a constant value, i.e. 0.75 (Montgomery, 1911; Ahmad et al., 2015; Aldesuquy et al., 2014).

\section{Root length measurement}

At the time of harvesting, the root length $(\mathrm{cm})$ of different treated plots calculated by measuring tape. The stems removed from the top portion of roots by a knife of each randomly selected plant. The total root length area from top to bottom measured compared to control (Fig. 3).

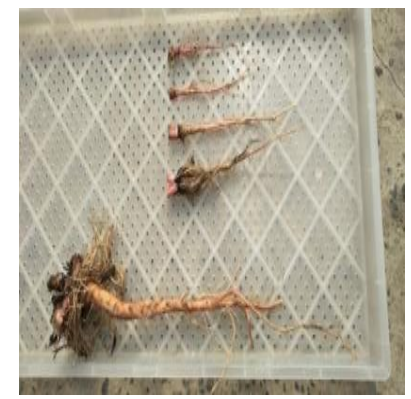

Figure 3. Comparison of treated with control roots of curled dock 


\section{Collection of yield data}

At the time of harvesting of wheat crops, yields recorded randomly from three positions of each treatment with $1 \mathrm{~m}^{2}$ quadratic rings. Wheat plants were then removed manually by sickles from these rings and harvested these with mini thresher and assessed grain yield (Scursoni et al., 2011).

\section{Statistical analysis}

The data anatomized statistically by analysis of variance in Duncan's Multiple Range test with P > 0.05 level of probability. The analysis performed by SPSS 13.0 (Inc.) software and interaction between the observed and predicted variables by using $\mathrm{R}$ package, version 3.5.2. (MuMin, 2018) moreover, graphical representations were framed on Sigma-Plot 10 software (Iqbal et al., 2018).

\section{Model validation}

The coefficient of determination relationship conceded out for developing the model for leaf area versus herbicide treatments and comparison of $R^{2}$ and RMSE. This model was set out to determine the effectiveness of leaf area $\left(\mathrm{cm}^{2}\right)$, and root length (cm) ultimately provide the information concerning model fitness of how far away the fitted line is from the reference line. The researchers previously exposed how condensed or scattered the observed values are around the fitted line, which alternatively revealed about the validity and model fitness (Hossain et al., 2017). RMSE used to evaluate the performance of the model in the curled dock: chemical herbicides (Debaeke et al., 1997; Ahmed et al., 2019).

\section{Results}

\section{Effect of herbicides on mortality}

The effect of herbicides on mortality of curled dock (30 DAS) progression and analysis of variance resulted year wise comparison stated highly significant $(\mathrm{P}<0.01)$ mortality $(91.16 \%)$ by Broad-X with standard deviation $(\mathrm{SD}=1.69)$, coefficient of variance $(\mathrm{CV}=13.11)$ and standard error $(\mathrm{SE}=4.788)$ after comparison with mean values by Duncan Multiple Range test. Clean wave followed this herbicidal treatment with statistically significant $(\mathrm{P}<0.05)$ mortality $(84.05 \%)$ with $\mathrm{SD}=1.64$ accordingly followed by Starane-M (79.92\%), however, the lowest mortality was recorded by Allymax (61.21\%) compared to control treatment during 2015-16 (Table 2).

The current research confirms the remarkable mortality of weed after the application of Broad-X $(91.55 \%)$ with a probability value $(\mathrm{P}<0.01)$ along with the SD (0.70) followed by clean wave $(82.01 \%)$; Starane-M (77.86\%). Allymax produced the lowest mortality (60.47\%) compared to control treatment during 2016-17 (Table 2).

On the other hand, after 15 DAS (days of spray) mortality (70.84\%) investigated by the application of Broad-X with $\mathrm{SD}=3.84$ differed statistically $(\mathrm{P}<0.05)$ with clean wave $(59.94 \%)$ along with rest of the treatments during 2016-17. In case of Broad-X $(72.93 \%)$ and clean wave $(63.52 \%)$ do not differ statistically from each other, but broad-X differed with Starane-M (56.57\%) and other treatments during 2015-16 (Table 2). 
Table 2. Effect of different herbicides on mortality percentage during 2015-16 and 2016-17

\begin{tabular}{c|c|c|c|c}
\hline \multirow{2}{*}{$\begin{array}{c}\text { Herbicides } \\
\text { treatments }\end{array}$} & \multicolumn{2}{|c|}{ Mortality (\%) 2015-16 } & \multicolumn{2}{c}{ Mortality (\%) 2016-17 } \\
\cline { 2 - 5 } & $\mathbf{1 5}$ DAS & $\mathbf{3 0 ~ D A S}$ & $\mathbf{1 5}$ DAS & 30 DAS \\
\hline Control & $0.000 \pm 0.00^{\mathrm{d}}$ & $0.000 \pm 0.00^{\mathrm{c}}$ & $0.000 \pm 0.00^{\mathrm{d}}$ & $0.000 \pm 0.00^{\mathrm{c}}$ \\
Starane-M & $56.57 \pm 3.80^{\mathrm{b}}$ & $79.92 \pm 4.41^{\mathrm{ab}}$ & $50.24 \pm 1.74^{\mathrm{c}}$ & $77.86 \pm 4.33^{\mathrm{ab}}$ \\
Clean wave & $63.52 \pm 3.08^{\mathrm{ab}}$ & $84.05 \pm 1.64^{\mathrm{a}^{*}}$ & $59.94 \pm 2.36^{\mathrm{b}}$ & $82.01 \pm 1.59^{\mathrm{ab}}$ \\
Broad-X & $72.93 \pm 4.25^{\mathrm{a}^{*}}$ & $91.16 \pm 1.69^{\mathrm{a}^{* *}}$ & $70.84 \pm 3.62^{\mathrm{a}^{*}}$ & $91.55 \pm 0.70^{\mathrm{a}^{* * *}}$ \\
Allymax & $48.73 \pm 0.59^{\mathrm{c}}$ & $61.21 \pm 17.85^{\mathrm{b}}$ & $44.40 \pm 2.44^{\mathrm{c}}$ & $60.47 \pm 20.21^{\mathrm{b}}$ \\
ANOVA & & & & 14.88 \\
C.V. & 6.06 & 13.11 & 5.22 & 5.35 \\
S. E. & 1.6795 & 4.788 & 1.36 & \\
\hline
\end{tabular}

DAS = days after spraying; $\mathrm{t}_{\mathrm{ha}}{ }^{-1}=$ ton per hectare. The same letters do not differ statistically from each other at $5 \%$ significance level. C. V. $=$ Coefficient of Variance; mean \pm SD (Standard Deviation). Maximum (SD) means the sample of weed population was collected in the field conditions having maximum weed population in a replication

The curled dock leaf area displayed a steep asymptotic decrease using different new chemical herbicides compared to before spraying. However the evaluations of leaf area versus herbicides measured quantitatively recorded strong positive coefficient of determination $R^{2}=0.94$ and $R^{2}=0.93,15$ and 30 days after treatment comparable before herbicide application as depicted (Fig. 4).

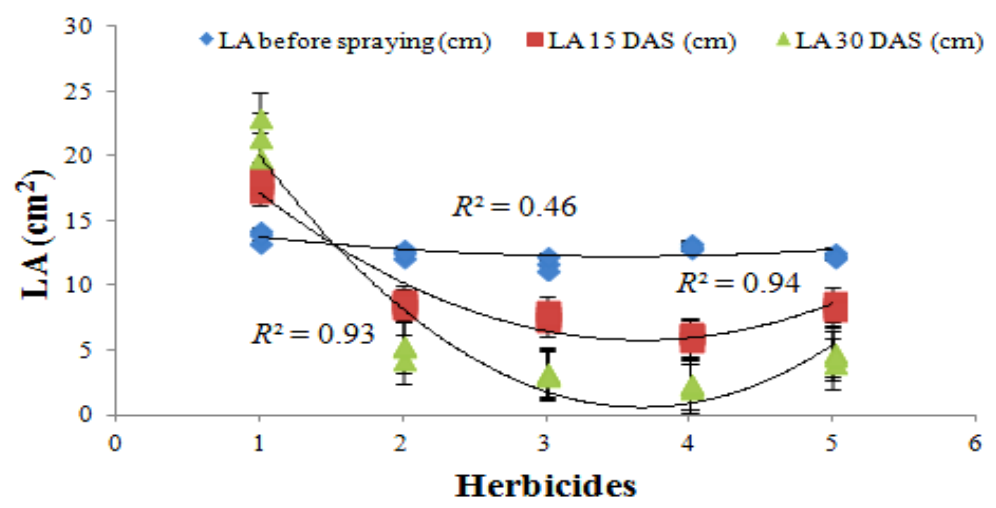

Figure 4. Power relation of leaf area with different herbicides used in the experiment $(1$ = control, $2=$ Starane $-M, 3=$ Clean wave, $4=$ Broad $X, 5=$ Allymax $)$ after 15,30 days during 2015-2016, LA = Leaf area, $R^{2}=$ Coefficient of determination, DAS = days after spraying, $\mathrm{cm}^{2}=$ centimeter square

In wheat crop, all herbicide treatments had a similar influence shown by the mild asymptotic upright curve on leaf area development compared to before foliar application with $R^{2}=0.40$ (Fig. 5). The recorded leaf area 15 and 30 days after foliar application of broad-X performed maximum outcome on the weed followed by clean wave herbicides indicated that broad-X herbicide was most effective and potential for controlling this invasive weed. The power relation in wheat crop performed better coefficient of determination $\left(R^{2}=0.93, R^{2}=0.88\right)$ indicated the evolution of observed leaf area recorded highly significant $(\mathrm{P}<0.01)$ relationship with the progression of predicted leaf area during 2016-17 (Fig. 5). 


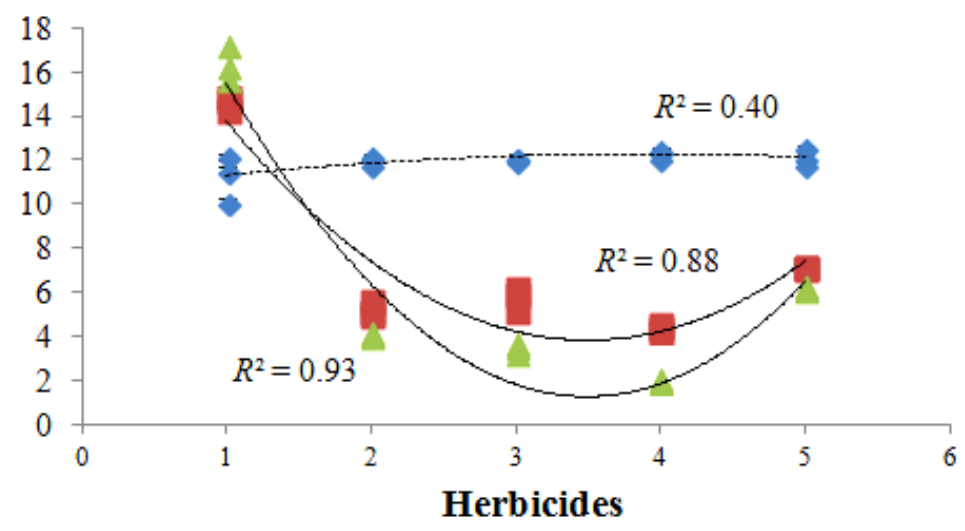

Figure 5. Power relationship of leaf area with herbicide treatments $(1=$ control, $2=$ Starane$M, 3=$ Clean wave, $4=$ Broad $X, 5=$ Allymax) used at 15, 30 days after spraying herbicides during 2016-17, $R^{2}=$ Coefficient of determination

\section{Response of herbicides with root damage (\%)}

The response of foliar herbicidal treatments performed statistically non-significant $(\mathrm{P}>0.05)$ reduction in root damage $(\%)$, however highly significant $(\mathrm{P}<0.001)$ responses were investigated by broad-X $(97.15 \pm 0.03 \% ; 98.25 \pm 1.08 \%)$ mean \pm sd and $(97.15 \pm 0.017 \% ; 98.25 \pm 0.0626 \%)$ on mortality of curled dock during both seasons (Fig. 6).

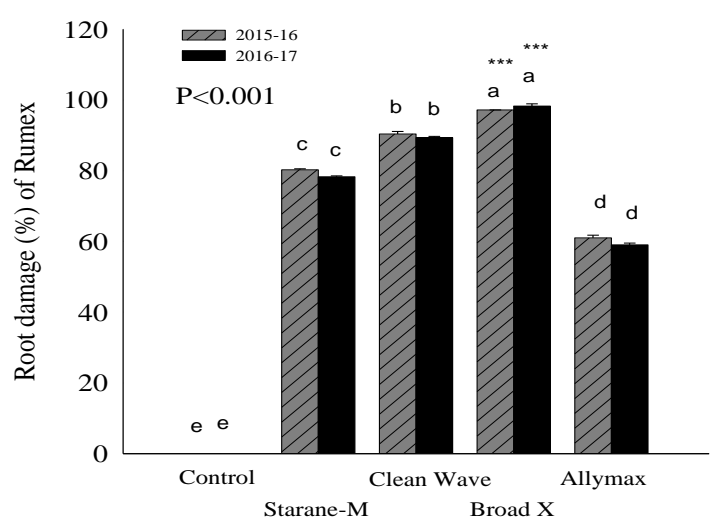

Figure 6. Efficacy of new chemistry foliar herbicides used for controlling curled dock and herbicides influence on root damage (\%) during 2015-16 \& 2016-17. The means having the same lettering do not differ statistically from each other. $* * *$ indicated difference among treatments of herbicides with root damage (\%) is highly significant

\section{Model validation performance of $R^{2}$}

The polynomial relationship during both years for all treatments performed comparable arc trends, ensuring a decline after full ground cover. The $R^{2}$ for root length $(0.93$ and 0.88$)$ were found statistically significant $(\mathrm{P}<0.001)$ strong positive relationship in regards to observed and predicted root length (RL) during both the years 
(Fig. 7) which indicated the best relation between two years resulting in the better fitting of the model.

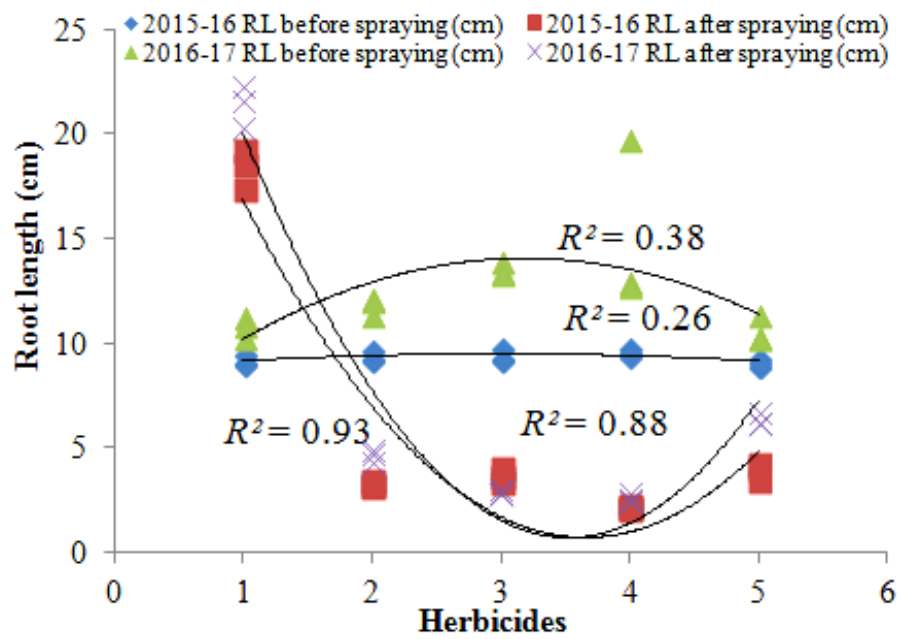

Figure 7. Efficacy of different herbicides on root length $(\mathrm{cm})$ of the curled dock during 2015-16 \& 2016-17. Whereas power relation Root Length with herbicides $(1=$ control, $2=$ Starane- $M$, $3=$ Clean wave, $4=$ Broad $X, 5=$ Allymax), $R^{2}=$ Coefficient of determination; $R L=$ Root length, $\mathrm{cm}=$ centimeter

\section{Impact of herbicides on yield}

Significant $(\mathrm{P}<0.001)$ yield $\left(3.43 \mathrm{t} \mathrm{ha}^{-1}\right)$ recorded by foliar application of Broad-X herbicides in a wheat crop with standard deviation (0.04); standard error (0.027) and coefficient of variance (1.71) during the first year 2015-16. Broad-X produced highly significant $(\mathrm{P}<0.001)$ yield $\left(3.69 \mathrm{t} \mathrm{ha}^{-1}\right)$ with $(\mathrm{sd}=0.09)$ and $\mathrm{se}=0.035$ compared to rest of the herbicides during 2016-17. Year-wise accumulation by ANOVA also stated highly significant yield $(\mathrm{CV}=1.97)$, however significant increase in yield produced by Broad-X (33.29\%) followed by clean wave (29.63\%) over control treatment (Table 3).

Table 3. Co-efficient of determination $\left(R^{2}\right)$ showing the effect of different herbicides on yield $\left(t h a^{-1}\right)$

\begin{tabular}{c|c|c|c|c|c}
\hline \multirow{2}{*}{$\begin{array}{c}\text { Herbicides } \\
\text { treatments }\end{array}$} & \multicolumn{2}{|c|}{ Yield $\left(\mathbf{t ~ h a}^{-\mathbf{1}}\right)$} & \multirow{2}{*}{$\boldsymbol{R}^{\mathbf{2}}$} & \multicolumn{2}{|c}{ RMSE } \\
\cline { 2 - 3 } \cline { 5 - 5 } & $\mathbf{2 0 1 5 - 1 6}$ & $\mathbf{2 0 1 6 - 1 7}$ & & $\mathbf{2 0 1 5 - 1 6}$ & $\mathbf{2 0 1 6 - 1 7}$ \\
\hline Control & $2.420^{\mathrm{e}}$ & $2.327^{\mathrm{e}}$ & 0.72 & 0.67 & 0.81 \\
Starane-M & $2.920^{\mathrm{c}}$ & $3.067^{\mathrm{c}}$ & 0.72 & 0.58 & 0.81 \\
Clean wave & $3.297^{\mathrm{b}^{* *}}$ & $3.447^{\mathrm{b}^{* *}}$ & 0.83 & 0.67 & 0.75 \\
Broad-X & $3.433^{\mathrm{a}^{* * *}}$ & $3.693^{\mathrm{a}^{* * *}}$ & 0.84 & 0.69 & 0.80 \\
Allymax & $2.693^{\mathrm{d}}$ & $2.800^{\mathrm{d}}$ & 0.71 & 0.33 & 0.47 \\
\hline
\end{tabular}

$* * \mathrm{P}<0.01 ; * * * \mathrm{P}<0.001$. The same letters do not differ statistically from each other. $R^{2}-$ Coefficient of determination; RMSE - root mean square error; $\mathrm{t}=$ tones; $\mathrm{ha}^{-1}=$ per hectare

\section{Model validation performance for RMSE}

Maximum yield was recorded by foliar application of Broad-X with a strong positive coefficient of determination $R^{2}(0.84)$ and $\operatorname{RMSE}(0.69$ and 0.80$)$. These results based on 
highly signified accurate conclusions when comparing focused treatments in both years. The polynomial relation for all herbicides for corresponding years also exposed a linear arc pattern which strung with an initial linear stage followed by maximum asymptotic trend at the growth stage by $R^{2}(0.83)$ with RMSE (0.67 and 0.75) also indicated the best relationship that specified the method accuracy (Table 3).

\section{Interaction of yield ( $\mathrm{t} \mathrm{ha} \mathrm{C}^{-1}$ ) with mortality (\%)}

In Table 4, maximum interaction in yield $\left(\mathrm{t} \mathrm{ha}^{-1}\right)$ with mortality (\%) of curled dock 15 and 30 days after spraying conferred highly significant $(\mathrm{P}<0.0001)$ performance during 2015-16 at Kharian. The interaction of yield versus herbicides 15 days after treatment and interaction of this with 30 days proved highly significant $(\mathrm{P}<0.0001)$ mortality $(\%)$ that showed better performance during 2016-17. However, yield recorded significant $(\mathrm{P}<0.05)$ interaction with mortality of curled dock 30 days after treatment (Table 4).

Table 4. Analysis of variance of factors affecting yield $\left(t \mathrm{ha}^{-1}\right)$ interaction with mortality 15 , 30 days after spraying postemergence herbicides

\begin{tabular}{c|c|c|c|c|c}
\hline Effect & D.f. & SS & MS & F & P \\
\hline \multicolumn{7}{c}{ (a) Yield (t ha $\mathbf{~}^{-1}$ ) during 2015-16 } \\
M15 & 1 & 7.221 & 7.221 & 849.99 & $<0.0001$ \\
M30 & 1 & 0.186 & 0.186 & 21.86 & $<0.0001$ \\
M15 x M30 & 1 & 0.938 & 0.938 & 110.40 & $<0.0001$ \\
Residuals & 41 & 0.348 & 0.008 & & \\
\hline \multicolumn{7}{c}{ (b) Yield (t ha ha $^{-1}$ during 2016-17 } \\
\hline M15 & 1 & 4.898 & 4.898 & 619.406 & $<0.0001$ \\
M30 & 1 & 0.023 & 0.023 & 2.953 & $<0.05$ \\
M15 x M30 & 1 & 1.144 & 1.144 & 144.647 & $<0.0001$ \\
Residuals & 41 & 0.324 & 0.008 & & \\
\hline
\end{tabular}

M15, M30 = Mortality after 15, 30 days of spray; the level of significance was $\mathrm{P}>0.05, \mathrm{P}<0.0001 * * *$; $\mathrm{P}<0.001^{* *} ; \mathrm{P}<0.01^{*} ; \mathrm{P}<0.05 ;$ D.f. = degree of freedom; $\mathrm{SS}=$ Sum of square; $\mathrm{MS}=$ Mean square; $\mathrm{F}$ and $\mathrm{P}$ values. DAS = days after spraying; $\mathrm{t}=$ tones; $\mathrm{ha}^{-1}=$ per hectare

\section{Discussion}

Curled dock (Rumex crispus L.) is a common perennial (Ulber, 2010) invasive weed species in wheat crop. This weed characterized by high ecological plasticity and ability to spread in the wheat crop from non-cropped vicinity. Due to its high exotic potential, this weed becomes most economically important and creates many problems in irrigated wheat ecosystems. This invasive weed species can control easily in the non-cropped area, but this weed shifted into the wheat fields. No doubt, curled dock populations scattered in some areas of District Gujrat (Tehsil Kharian and Gujrat) in patches.

Broad-leaved dock is a common and troublesome grassland weed with a wide geographic distribution. In conventional farming, Curled dock managed by selective herbicides, however in an organic farming destructive method is the best option (van Evert et al., 2011) but it is laborious in large scale.

The studied chemicals (Table 1) disrupt hormone balance; protein syntheses in the curled dock and cause a variety of plant growth abnormalities. Cleave wave act as a growth regulator is synthetic auxin's (Yerkes et al., 2014) travel equally upward and 
downward inside the phloem to the growing points of the shoots and roots. Many herbicides in phenoxy acetic acids group are effective on perennial and annual broadleaf weeds (Gunsolus and Curran, 1999). Allymax selectively inhibits broad leaves by acetolactate syntheses ALS due to its systemic action. This herbicide belongs to sulfonylurea (SU) one of the most critical classes of herbicides worldwide. It is well known for its eco-friendly, extremely low toxicity towards mammals (Li et al., 2012). These are selective herbicides that kill dicots, sensitive to auxinic herbicides include abnormal growth, senescence, and plant death without affecting monocots (Song, 2014).

Weed management is significantly principal activity on agricultural and nonagricultural lands but faced with many types of challenges. There is a need to adopt broad-spectrum new approaches for its management strategies (Liebman et al., 2016; Calado et al., 2010). Therefore, critical challenges for invasive weed supervision comprised territory wise obstacle of weed emergence and expansion of cost-effective strategies would adopt for the control of invader (Buckley and Han, 2014) including biological control agents.

The response of foliar herbicide on mortality of curled dock performed highly significant $(\mathrm{P}<0.001)$ responses by the application of Broad-X which is the combination of three herbicides $(97.15 \pm 0.03 \%$; $98.25 \pm 1.08 \%)$, i.e. (mean \pm sd) and $(97.15 \pm 0.017 \% ; 98.25 \pm 0.0626 \%)$, i.e. (mean \pm se) have a more significant potential for controlling curled dock under irrigated system of Gujrat (Table 2). The experimental effect was in agreement to Cheema et al. (2006) who described that the use of broadleaved herbicides controlled maximum Chenopodium album. Curled dock controlled by Propanil herbicide (Price and Kelton, 2013) however, common sorrel (Rumex acetosa) species were susceptible to postemergence MCPA (Marshall et al., 2003) in wheat crops.

The study results were also in agreement with (Usman et al., 2010), who illustrated that 2,4-dichlorophenoxy acetic acid was effective for the better management of broadleaf dock (Rumex dentatus) in wheat crops. The previously described results against broadleaf dock were reported by (Naseer-ud-Din et al., 2011) that 2,4dichlorophenoxy acetic acid (Bromoxynil + MCPA @ $0.49 \mathrm{~kg}$ a.i ha ${ }^{-1}$ ) gave better performance compared to Pyroxasulfone @ $0.15 \mathrm{~kg}$ a.i ha ${ }^{-1}$ against Indian dock/broadleaved dock ( $R$. dentatus) species in wheat crops during 2008-2009. These results are following the researchers who reported that the broadleaf dock ( $R$. dentatus) having an identical family was controlled inadequately with 2,4-D. while, halauxifen + florasulam used @ $12.76 \mathrm{~g}$; metsulfuron $4 \mathrm{~g}$ and etsulfuron + carfentrazone @ 4+20 g a.i ha ${ }^{-1}$ provided absolute control (Chhokar et al., 2015).

Isoproturon sprayed @ $1080 \mathrm{~g}$ a.i ha ${ }^{-1}$ reduced the density of Indian dock significantly (Shehzad et al., 2012).

The researchers reported that herbicides are most effective for controlling curled dock in their field experiments (Humphreys et al., 1999; Benvenuti et al., 2001; Eekeren et al., 2006). Maximum mortality investigated by Sulfosulfuran + Metsulfuran (92.27\%) followed by Metsulfuran ( $81.69 \%$ ) against this invasive weed after 30 days of spraying herbicides (Singh et al., 2017). Results of this and previous studies indicated that 2,4DB (Butyrac 200) and Asulam @ $1.5 \mathrm{lb}$ a.i acre $^{-1}$ (Asulox) provide better control efficacy against the dock in red clover field (Roerig et al., 2015).

The toxic effect of herbicides inhibited the growth of plants resulted in plant death. Scientists reported that herbicides killed weeds up to $90.5-94.1 \%$ after fifteen days of spraying; however, $100 \%$ mortality investigated after 21 days of foliar application 
(Dimitrova and Marinov-Serafimov, 2008). Different doses of sulfosulfuron controlled weeds up to $98.7 \%$ (Paswan et al., 2017). Premix application of sulfosulfuron and metsulfuron methyl used @ $30+2 \mathrm{~g} \mathrm{ha}^{-1}$ at 60 DAS was recorded highest mortality (\%) compared to control treatment. Clodinofop + Metsulfuron methyl @ $60+4 \mathrm{~g}$ ai ha ${ }^{-1}$ was exercised by $(91.75 \%)$ control followed by Sulfosulfuron @ $25 \mathrm{~g} \mathrm{ha}^{-1}(87.60 \%)$ and Isoproturon +2,4-D @ $1000+400 \mathrm{~g}$ ai ha $^{-1}(87.42 \%)$ in the wheat crop after 90 days of post emergence application (Choudhary et al., 2016).

The studied leaf area of curled dock exhibited a steep declining curvature using different herbicides, which was comparable with low asymptotic development before spraying. The stable positive coefficient of determination developed in both of the seasons compared to control treatment (Figs. 4 and 5). Experimental findings correlate with previously reported work that leaf area measured exposed excellent performance $R^{2}=0.88$ and $\mathrm{RMSE}=0.96$. These results are conformity to (Ahmad et al., 2015) who reported $R^{2}=0.59$ in wheat crops by destructive method compared to non-destructive. The broadleaf dock ( $R$. dentatus) controlled significantly by using different treatments; however, the effect of the relationship between crop succession and weed control treatments was significant (Fakkar and El-Dakkak, 2015).

Statistically yield (3.43 $\mathrm{t} \mathrm{ha}^{-1}$ ) recorded by foliar application of Broad-X herbicides in a wheat crop. The results of this study confirmed with (Malekian et al., 2013; Steckel et al., 1997) who recorded foliar spray of metsulfuron-methyl + sulfosulfuron @ 36g.a.i.ha ${ }^{-1}$ effectively controlled annual weed resulting in the highest yield of the wheat crops. Scientists previously revealed that severe infestation of weed plants in wheat crops resulting in 18-73\% reduction in grain yield (Pandey et al., 2006). The researchers also described in their experiments that the mixture of Metsulfuran and Sulfosulfuron performed more efficient control with their foliar application resulting higher yield of crops (Singh et al., 2011). The model of density inhibition exposed effectively against the broadleaved dock; however its density reduced up to $69-88 \%$, and wheat yield was enhanced up to $22-48 \%$ compared to control treatment by the application of Atlantis 3.6WG @14.4 g a.i ha-1 (Khaliq et al., 2011).

The invasive weed deteriorates the quality of grain by creating hindrance in cultural practices, i.e. fertilizer application and irrigation (Memon et al., 2003). The yield reduced up to $20-30 \%$ by the attack of broad-leaved weeds in wheat crop (Ashok et al., 2006). Due to the hard nature and invasiveness of curled dock, effective combinations of herbicides recommended for its better management.

\section{Conclusion}

Based on our knowledge, this is an exclusive comparative study in which the author used an applied combination of herbicides already present in the market having two and or three chemicals for controlling curled dock in wheat crops. These results screened out Broad-X herbicide performed better against the curled dock followed by Clean Wave in wheat crops. According to the above analysis and findings, the farmers in this region advised using these postemergence herbicides for controlling this toxic weed in ordered to obtain higher yield. We encouraged researchers to explore the mode of action, resistance mechanism of these herbicides and to find out suitable biological control agents (BCA's) against this toxic weed in future. 
Acknowledgements. This study was supported by the National Key R\&D Program of China (2017YFC1200101), the National Natural Science Foundation of China $(31470575,31670545$ and 31971557).

Conflict of interests. All authors declare no conflict of interests.

Ethical approval. This research was two years field experiments to check out the efficacy of post emergence herbicides against this invasive weed (curled dock) which can consider a risk to the wheat growers in future.

\section{REFERENCES}

[1] Ahmad, S., Ali, H., Ur Rehman, A., Khan, R. J. Z., Ahmad, W., Fatima, Z., Abbas, G., Irfan, M., Ali, H., Khan, M. A. (2015): Measuring leaf area of winter cereals by different techniques: a comparison. - Pak. J. Life Soc. Sci 13: 117-125.

[2] Ahmed, M., Ji, M., Qin, P., Gu, Z., Liu, Y., Sikandar, A., Iqbal, M. F., Javeed, A. (2019): Phytochemical screening, total phenolic and flavonoids contents and antioxidant activities of Citrullus colocynthis L. and Cannabis sativa L. - Applied Ecology and Environmental Research 17: 6961-6979.

[3] Aldesuquy, H., Baka, Z., Mickky, B. (2014): Kinetin and spermine mediated induction of salt tolerance in wheat plants: Leaf area, photosynthesis and chloroplast ultrastructure of flag leaf at ear emergence. - Egyptian Journal of Basic and Applied Sciences 1: 77-87.

[4] Alvi, S. M., Sanaullah, C., Ali, M. A. (2004): Evaluation of some herbicides for the control of weeds in wheat crop. - Pak. J. Life Soc. Sci 2: 24-27.

[5] Ashok, K., Malik, R. K., Hasija, R. C. (2006): Efficacy of metribuzin alone and as tank mixture with different herbicides against weeds in wheat. - Environment and Ecology 245: 1046-1049.

[6] Benvenuti, S., Macchia, M., Miele, S. (2001): Light, temperature and burial depth effects on Rumex obtusifolius seed germination and emergence. - Weed Research 41: 177-186.

[7] Buckley, Y. M., Han, Y. (2014): Managing the side effects of invasion control. - Science 344: 975-976.

[8] Calado, J. M. G., Basch, G., de Carvalho, M. (2010): Weed management in no-till winter wheat (Triticum aestivum L.). - Crop Protection 29: 1-6.

[9] Chaudhry, S., Hussain, M., Ali, M. A., Iqbal, J. (2008): Efficacy and economics of mixing of narrow and broad leaved herbicides for weed control in Wheat. - Journal of Agricultural Research 46: 355-360.

[10] Cheema, M. S., Akhtar, M., Iqbal, M. S. (2006): Performance of different herbicides in wheat under irrigated conditions of Southern Punjab, Pakistan. - Pakistan Journal of Weed Science Research 12: 53-59.

[11] Chhokar, R. S., Sharma, R. K., Gill, S. C., Meena, R. P. (2015): Herbicides for broadleaved weeds management in wheat. - Indian J. Weed Sci 47: 353-361.

[12] Choudhary, D., Singh, P. K., Chopra, N. K., Rana, S. C. (2016): Effect of herbicides and herbicide mixtures on weeds in wheat. - Indian Journal of Agricultural Research 50: 107112.

[13] Crone, E. E., Marler, M., Pearson, D. E. (2009): Non-target effects of broadleaf herbicide on a native perennial forb: a demographic framework for assessing and minimizing impacts. - Journal of Applied Ecology 46: 673-682.

[14] Dalga, D., Sharma, J. J., Tana, T. (2014): Growth and yield of bread wheat (Triticum aestivum L.) as influenced by row spacing and weeding frequency in Southern Ethiopia. Scientia 8: 19-30.

[15] Dalley, C. D., Bernards, M. L., Kells, J. J. (2006): Effect of weed removal timing and row spacing on soil moisture in Corn (Zea mays). - Weed Technology 20: 399-409. 
[16] Davis, A. S., Hall, J. C., Jasieniuk, M., Locke, M. A., Luschei, E. C., Mortensen, D. A., Riechers, D. E., Smith, R. G., Sterling, T. M., Westwood, J. H. (2009): Weed science research and funding: a call to action. - Weed Science 57: 442-448.

[17] Debaeke, P., Caussanel, J. P., Kiniry, J. R., Kafiz, B., Mondragon, G. (1997): Modelling crop: weed interactions in wheat with ALMANAC. - Weed Research 37: 325-341.

[18] Délye, C., Jasieniuk, M., Le Corre, V. (2013a): Deciphering the evolution of herbicide resistance in weeds. - Trends in Genetics 29: 649-658.

[19] Délye, C., Menchari, Y., Michel, S., Cadet, É., Le Corre, V. (2013b): A new insight into arable weed adaptive evolution: mutations endowing herbicide resistance also affect germination dynamics and seedling emergence. - Annals of Botany 111: 681-691.

[20] Dimitrova, T., Marinov-Serafimov, P. (2008): Chemical control of curled dock (Rumex crispus L.) and other weeds in noncropped areas. - Pestic. Phytomed. (Belgrade) 23: 123126.

[21] Duke, S. O. (2012): Why have no new herbicide modes of action appeared in recent years? - Pest Management Science 68: 505-512.

[22] Eekeren, V. N., Fehér, L., Smeding, F., Prins, U., Jansonius, P. (2006): Controlling broad-leaved dock (Rumex obtusifolius) in grass clover mixtures. - Sustainable Grassland 11:391-393.

[23] Fakkar, A. A. O., El-Dakkak, A. A. A. (2015): Effect of crop sequence and weed control treatments on weeds and pea crop productivity. - Annals of Agricultural Sciences 60: $157-168$.

[24] Gunsolus, J. L., Curran, W. S. (1999): Herbicide mode of action and injury symptoms. Order 612: 625-8173.

[25] Hossain, S. A. A. M., Wang, L., Chen, T., Li, Z. (2017): Leaf area index assessment for tomato and cucumber growing period under different water treatments. - Plant, Soil and Environment 63: 461-467.

[26] Humphreys, J., Jansen, T., Culleton, N., MacNaeidhe, F. S., Storey, T. (1999): Soil potassium supply and Rumex obtusifolius and Rumex crispus abundance in silage and grazed grassland swards. - Weed Research (Oxford) 39: 1-13.

[27] Iqbal, M., Hussain, M. M., ur Rehman, K., Shah, M., Iqbal, M. F., Hussain, M., Iqbal, Z. Aatika, S. (2018): Evaluation of new chemistry insecticides for controlling invasive pest in citrus orchard. - International Journal of Advance Research in Biological Sciences 5: 100-105.

[28] Khaliq, A., Matloob, A., Tanveer, A., Areeb, A., Aslam, F., Abbas, N. (2011): Reduced doses of a sulfonylurea herbicide for weed management in wheat fields of Punjab, Pakistan. - Chilean Journal of Agricultural Research 71: 424.

[29] Li, Z.-M., Ma, Y., Guddat, L., Cheng, P.-Q., Wang, J.-G., Pang, S. S., Dong, Y.-H., Lai, C.-M., Wang, L.-X., Jia, G.-F., Li, Y.-H., Wang, S.-H., Liu, J., Zhao, W.-G., Wang, B.-L. (2012): The structure-activity relationship in herbicidal monosubstituted sulfonylureas. Pest Management Science 68: 618-628.

[30] Liebman, M., Baraibar, B., Buckley, Y., Childs, D., Christensen, S., Cousens, R., Eizenberg, H., Heijting, S., Loddo, D., Merotto, A. (2016): Ecologically sustainable weed management: How do we get from proof-of-concept to adoption? - Ecological Applications 26: 1352-1369.

[31] Malekian, B., Ghadiri, H., Kazemeini, S. A., Edalat, M. (2013): Evaluation of sulfosulfuron, metsulfuron-methyl plus sulfosulfuron, mesosulfuron-methyl plus iodosulfuron-methyl and iodosulfuron plus mesosulfuron herbicides in winter Wheat (Triticum aestivum L.). - J. Biol. Environ. Sci 7: 177-182.

[32] Marshall, E. J. P., Brown, V. K., Boatman, N. D., Lutman, P. J. W., Squire, G. R., Ward, L. K. (2003): The role of weeds in supporting biological diversity within crop fields. Weed Research 43: 77-89. 
[33] Marwat, K. B., Muhammad, S., Zahid, H., Bakhtiar, G., Haroon ur, R. (2008): Study of various herbicides for weed control in wheat under irrigated conditions. - Pakistan Journal of Weed Science Research 14: 1-8.

[34] Marwat, S. K., Usman, K., Khan, N., Khan, M. U., Khan, E. A., Khan, M. A., ur Rehman, A. (2013): Weeds of wheat crop and their control strategies in dera Ismail khan district, Khyber Pakhtun Khwa, Pakistan. - American Journal of Plant Sciences 4: 66.

[35] Memon, R., Raza Bhatti, G., Khalid, S. (2003): Weed diversity of wheat crop in Khairpur District, Sindh. - Pakistan Journal of Weed Science Research 9(1-2): 99-103.

[36] Montgomery, E. G. (1911): Correlation studies in corn. - Neb. Agric. Exp. Stn. Annu. Rep 24: 108-159.

[37] Moss, S., Ulber, L., Den Hoed, I. (2019): A herbicide resistance risk matrix. - Crop protection 115: 13-19.

[38] MuMin, B. K. (2018): Multi-model inference. - R package version 1.15. 6.

[39] Naseer-ud-Din, G., Shehzad, M., Nasrullah, H. M. (2011): Efficacy of various pre and postemergence herbicides to control weeds in wheat. - Pakistan Journal of Agricultural Sciences 48: 185-190.

[40] Nayyar, M. M., Shafi, M., Mahmood, T., Randhwa, A. M. (1994): Effect of herbicides on monocot weeds in wheat. - Journal of Agriculture Research 32: 149-155.

[41] Pandey, A. K., Gopinath, K. A., Gupta, H. S. (2006): Evaluation of sulfosulfuron and metribuzin for weed control in irrigated wheat (Triticum aestivum L.). - Indian Journal of Agronomy 51: 135-138.

[42] Paswan, A. K., Mandal, D., Kumar, J., Kumar, R. (2017): Influence of weed management practices on productivity of wheat (Triticum aestivum L.) under Middle Indo-Gangetic Plains of Eastern India. - International Journal of Current Microbiology and Applied Sciences 6: 2486-2491.

[43] Price, A. J., Kelton, J. A. (2013): Integrating Herbicides in a High-Residue Cover Crop Setting. - In: Price, A., Kleton, J. (eds.) Herbicides. Current Research and Case Studies in Use. IntechOpen, London.

[44] Qureshi, R., Waheed, A., Arshad, M. (2009): Weed communities of wheat crop in District Toba Tek Singh, Pakistan. - Pakistan Journal of Botany 41: 239-245.

[45] Roerig, K. C., Anderson, N. P., Hulting, A. G., Curtis, D. W., Mallory-Smith, C. A. (2015): Evaluation of Asulam and 2, 4-DB Crop Safety and Dock Control in Red Clover Grown for Seed. - Seed Production Research at Oregon State University, CrS 152.

[46] Schuster, T. M., Reveal, J. L., Bayly, M. J., Kron, K. A. (2015): An updated molecular phylogeny of Polygonoideae (Polygonaceae): Relationships of Oxygonum, Pteroxygonum, and Rumex, and a new circumscription of Koenigia. - Taxon 64: 11881208.

[47] Scursoni, J. A., Martín, A., Catanzaro, M. P., Quiroga, J., Goldar, F. (2011): Evaluation of postemergence herbicides for the control of wild oat (Avena fatua L.) in wheat and barley in Argentina. - Crop Protection 30: 18-23.

[48] Shehzad, M., Tanveer, A., Ayub, M., Mubeen, K., Ibrahim, M., Qadir, I., Sarwar, N. (2013): Effect of weed-crop competition on growth and yield of Garden Cress. - Sarhad Journal of Agriculture 29: 79-82.

[49] Shehzad, M. A., Nadeem, M. A., Sarwar, M. A., Naseer-ud-Din, G. M., Ilahi, F. (2012): Comparative efficacy of different postemergence herbicides in wheat (Triticum aestivum L.). - Pak. J. Agri. Sci 49: 27-34.

[50] Siddiqui, I., Bajwa, R. (2010): Effect of six problematic weeds on growth and yield of wheat. - Pak. J. Bot 42: 2461-2471.

[51] Singh, A. K., Kumar, R., Singh, A. K., Singh, N. K., Kumari, A. (2011): Performance of sulfosulfuron against weeds in irrigated wheat (Triticum aestivum L.). - CAB Abstracts Environment and Ecology 29: 831-833. 
[52] Singh, S., Singh, A. K., Yadav, A., Harikesh, S. (2017): Assess the effect of different combinations of herbicides on weed population and economic feasibility of treatments in late sown wheat crop. - Journal of Pharmacognosy and Phytochemistry 5: 648-651.

[53] Song, Y. (2014): Insight into the mode of action of 2, 4-dichlorophenoxyacetic acid (2, 4-D) as an herbicide. - Journal of Integrative Plant Biology 56: 106-113.

[54] Steckel, G. J., Wax, L. M., Simmons, F. W., Phillips, W. H. (1997): Glufosinate efficacy on annual weeds is influenced by rate and growth stage. - Weed Technology 11: 484488.

[55] Ulber, L. (2010): Weed species diversity in cropping systems: management and conservation strategies. - .

[56] Usman, K., Khalil, S. K., Khan, A. Z., Khalil, I. H., Khan, M. A. (2010): Tillage and herbicides impact on weed control and wheat yield under rice-wheat cropping system in Northwestern Pakistan. - Soil and Tillage Research 110: 101-107.

[57] van Evert, F. K., Samsom, J., Polder, G., Vijn, M., Dooren, H. J. v., Lamaker, A., van der Heijden, G. W. A. M., Kempenaar, C., van der Zalm, T., Lotz, L. A. P. (2011): A robot to detect and control broad-leaved dock (Rumex obtusifolius L.) in grassland. - Journal of Field Robotics 28: 264-277.

[58] Waheed, A., Qureshi, R., Jakhar, G. S., Tareen, H. (2009): Weed community dynamics in wheat crop of District Rahim Yar Khan, Pakistan. - Pakistan Journal of Botany 41: 247254.

[59] Westwood, J. H., Charudattan, R., Duke, S. O., Fennimore, S. A., Marrone, P., Slaughter, D. C., Swanton, C., Zollinger, R. (2018): Weed management in 2050: Perspectives on the future of weed science. - Weed Science 66: 275-285.

[60] Yerkes, C. N., Mann, R. K., Satchivi, N. M., Schmitzer, P. R. (2014): Herbicidal compositions comprising 4-amino-3-chloro-5-fluoro-6-(4-chloro-2-fluoro-3methoxyphenyl) pyridine-2-carboxylic acid or a derivative thereof and synthetic auxin herbicides. - Google Patents.

[61] Zaller, J. G. (2004a): Ecology and non-chemical control of Rumex crispus and $R$. obtusifolius (Polygonaceae): A review. - Weed Research 44: 414-432.

[62] Zaller, J. G. (2004b): Competitive ability of Rumex obtusifolius against native grassland species: above- and belowground allocation of biomass and nutrients. - Journal of Plant Diseases and Protection 19: 345-351.

[63] Zimdahl, R. L. (2018): Fundamentals of Weed Science. - Academic Press, San Diego. 